\title{
Strategies for Capacity Building in Implementing the Village Fund
}

\author{
Mrs. Payao Laonet 1 \\ Asst. Prof. Dr. Suphawan Vongkamjan ${ }^{2}$ \\ Prof Dr. Anurak Panyanuwat ${ }^{3}$
}

1. Ph.D. Candidate Student of Development Strategy Program, Nakhon Sawan Rajabhat University. 2. Major Advisor, Development Strategy Program, Nakhon Sawan Rajabhat University. 3. Development Strategy Program, Nakhon Sawan Rajabhat University.

\section{Doi: 10.5901/mjss.2013.v4n4p131}

\begin{abstract}
The objectives were 1) to formulate strategies for capacity building in the village fund implementation, and 2) to experiment and evaluate the strategies for capacity building in the village fund implementation. Qualitative research and quantitative research approaches were used. Data collection and analysis were done with In-Depth interview and focus group discussion for qualitative research. The experiment group composed of 12 groups of the village fund board committees and members in Khao Thong Sub-district, Payuhakiri District, Nakhon Sawan Province. The results of strategic formulation for capacity building in implementing the village fund was composed of 4 system units as the followings. 1. Aim to Community monetary institute, 2. Systemic Administration 3. Accounting System Management, 4. Creation of Strength and Sustainability. The experimental results of the 72 members of village fund showed that their achievement of knowledge, attitude and practical skill had mean different scores of 6.79 between pretest and posttest with statistically significant at level of 0.001 . Their satisfactions after training were at high level for 14 aspects and at highest level for 1 aspect.
\end{abstract}

Key Words: Strategy, Capacity Building, Performance, Village Fund

\section{Introduction}

The Eighth Economic and Social Development Plan (1997-2001) paid attention to the participation of all sectors of society and aimed to "People centered of development" by using economy as tool for development to assist people to be happy and to have a better life quality. Simultaneously, the development mean has adjusted to be holistic more than separated development in order to make a balance among economic, social, and environmental development. At the first year of this plan, Thailand faced with vigorously economic crisis that affected to different people and every sector of society. Therefore, it needs to restore the economic stability and to decrease economic impact. Due to economic crisis, it caused the unemployment and poverty increasingly. Afterward, in the Ninth Economic and Social Development Plan (20022006), national economic committee invited "Sufficiency Economy" philosophy according to various royal addresses of His Majesty the King lead for development will be humble appealed to as guiding philosophy of national development together with a broad people participation process involving participants from all segments of the Thai society based on the "Human as development center" has continued from the Eighth National Plan by emphasizing on the importance of economic problem solving. Building the main aim to internal economy to be strong and to have immunity for external dynamic change, the development had aim to make a balance among man, society, economy and environment to accomplish the sustainable development, wellness and happiness of Thai people. The results of development mostly successes in all aspects but the economic problem is still not strong and stable to the external variations. The poverty, unequal income and without transparency of governmental administration during the Tenth National Plan between B.E. 2550-2550, Thailand had still faced with important changes in different situation in both opportunity and restriction such as the technological change with over jumping to create change in both economic and social aspects for opportunity and threat. Therefore, it needs to manage the body of knowledge systemically and to apply appropriate technology to integrate in the strength of Thai society with the preparedness of people and system to be able to search benefit and to keep up with globalization. Moreover, the immunity is also need to create for all segments of society according to Sufficiency Economy philosophy (The National Economic Development Board Office of the Prime Minister, 1997; The 
National Economic Development Board Office of the Prime Minister, 2002; The National Economic Development Board Office of the Prime Minister, 2007).

Presently, the country development is in the Eleventh National Plan (2012-2016). It has still emphasized to bring avoidable immunity and to build internally strong immunity to prepare the people, society, and economic system to be able to support the impact of change properly. It is important to emphasize people and Thai society to develop with quality and obtain benefit from the economic and social development equally. In additionally, it must be created the economic opportunity based on knowledge, technology, innovation, and creative thinking on basis of production and consumption with friendly sound environment, therefore they need to provide administrative plan to cause the practice objectively. This will lead to profit for sustainable and happiness for Thai society according Sufficiency Economy philosophy (The National Economic Development Board Office of the Prime Minister, 2013).

The social status of Thailand is the people development at middle class level, but the education has highly extended in term of quantity but they are still lack of competency to lead the knowledge to use at low level. The productivity in terms of high skilled labor is still lag. The community status, it is found that Thai society has adjusted to enter to the age of rural change to urban continuously with the separated parts and this caused imbalance of life quality. The materialism of living pushes them into consumerism behavior with high convenient lifestyles but lesser happiness because the income is inadequate for the expense. The debt in community grows higher and higher, therefore the relationships in community people have isolated living. The direction of country adjustment should pay attention to the creation of system and internal structure to be capable to self-dependence by building the immunity with sufficiency economy. It aims to develop people in all dimensions of physical, mental, and intellectual to make a secured and warm family to meet a strong community together as network of development and to support competency and basic economic immunity of country.

However, the country development aims to village or community mainly because when the village and community are strong, therefore they can overcome the economic crisis easily and lead to sustainable development. The government has set the strategy for country administration into 3 groups included building strong social fundament, reform the governmental system according to good governance and develop country to enter to new economic age with keep up with the global change and self-dependency (Thiengkamol, 2007; The National Economic Development Board Office of the Prime Minister, 2002; The National Economic Development Board Office of the Prime Minister, 2007).

The village and urban community fund policy is an urgent policy of government to aim for diminishing the poverty problem for majority people of country who lacked of an opportunity to reach capital sources for career development and alleviate the emergent and hurried up needs. The government support a village or a community with one million baht fund as capital source for rotating to build occupation, work, income building, expense decreasing and to develop welfare and security for people in village to promote and develop village to increase people competency. The systemic administration and fund management to make a process of self-dependence are stimulated by this fund to support strength, economic immunity, village and urban community society; therefore in order to create the sustainability of fundamental level of country in the future, this strategy was introduced for the concept to provide a change for household, community, community organization, and community network to have capital sources with low interest and easily to reach. It is stimulation for purchasing power and production power to make a occupation and secure income and capital accumulation at social fundamental level together with promoting and supporting the local learning and learning process to develop the community competency to make community strength and sustainability from work completed implementation for a year. This indicated that mentioned policy is able to create an opportunity to reach capital sources by transferring money to village and urban communities with 73,441 funds or 73,441 million baht. The fund members used for agricultural activities with 71.91 percents, industrial activity with 4.08 percents, and merchant with 16.33 percents. Moreover, these made directive learning for committee through training of administrative knowledge, accounting management, fund bachelor to help for implementing in each village of 68,994 peoples and caused increased fund by saving with $4,459.50$ million baht and accumulated interest 354.10 million baht. In the aspect of quality, it is implemented for various capacity building of village fund such as educational tour project, arrangement of learning stage, network development, knowledge distribution project, and people participation of 3,384,443 fund members and 1,077,077 fund committees. The problem and obstacle of implementation are knowledge and understanding in regulations, rules, allocation, and money transferring, withdrawing loan, and work mechanism of implementation of subcommittee at different levels at provincial, district, and sub-district levels. Moreover, there are arrangement of increased efficiency project, competency building project and public relation )National Village and Urban Community Fund Office, 2012(

Implementation during periods of B.E. 2544-2549, there are the whole number of 11,626,200 fund members, and member with loan of $10,079,915$ peoples. The money loan of $246,374.38$ million baht were loaned for production, merchant, and service with 81.3 percent, loan for emergency case with 14.5 percents, paying for informal debt with 3.2 
percents, and other 1.0 percent. The loan for grouping activities of 2,948 groups were 79,025 cases with total 1,027.95 million baht were used for supportive activities of "One Tambon One Product or One District One product" for 327,778 cases with 4,296.67 million baht. The member without loan was 13.3 percents. There was transferring money to village and urban community with 77,508 funds or 98.32 percents (Saengthong, 2007; National Village and Urban Community Fund Office, 2010).

The results of this holistic view, it is obviously seen that Village and Urban Community Fund has extended both in terms of saving, increased fund, and member number make a participation, make a job and career to alleviate the urgent case for numerous members. Considering to each fund, it was found that there are a lot of fund enabling to implement to accomplish the targets strongly and make a learning to connect to learning network but a numerous funds were still not able to meet their targets effectively according the philosophy of Village and Urban Community Fund since the amount of money was supported from governmental allocation is also increasing as well. Therefore, the subsidy money of interest and member saving, member number is still not solved systemically both in terms of administration and career development. Therefore, it must to search a guideline for developing implementation system in form of competency development for career. If any village fund did not develop and had no good implementation system, the fund would face with problem of lack of implementation competency, strength and sustainability. It will have gap of corruption, debt accumulation of loan member and this would make the fund could not support and make benefit to members and village according to philosophy and objective fund. This makes a serious problem member life quality and loss in economic system. Therefore, to search strategy for creating implementation efficiency of village fund in this research. It would start at fundamental building of people and community to be strong by studying from the real situation in the area that is ready to be driven. The villages in Khao Thong Sub-district, Payuhakiri District, Nakhon Sawan Province were conducted for experimenting the strategies for capacity building in implementing the village fund (Khao Thong Sub-district, 2011).

\section{Objective}

The research objectives were as followings:

1) To formulate strategies for capacity building in the village fund implementation.

2) To experiment and evaluate the strategies for capacity building in the village fund implementation.

\section{Methodology}

The research design was implemented in steps by step as followings:

1. The qualitative research was used for strategies for capacity building in implementing the village fund. InDepth Interview was used for data collection from 6 peoples of 1 district developer, 1 district agriculturist, 1 Khao Thong Sub-district leader, 1 bank manager, 1 Payuhakiri District network leader, and 1 Khao Thong Sub-district fund bachelor were used for searching problems, needs, developmental needs, and required future oriented (Thiengkamol, 2011a). Focus group discussion was conducted with 12 village fund presidents, 6 village fund members with totally 18 peoples (Thiengkamol, 2011a). There were 4 units of working systems of strategic formulation including;

1.1 Aim to Community monetary institute

1.2 Systemic Administration

1.3 Accounting System Management

1.4 Creation of Strength and Sustainability

The quantitative research was used for experimenting strategies for capacity building in implementing the village fund. The experiment group composed of 72 members of village fund and was selected with Purposive Sampling Technique.

\section{Results}

\subsection{In-Depth Interview Results}

The selected 6 peoples of 1 district developer, 1 district agriculturist, 1 Khao Thong Sub-district leader, 1 bank manager, 1 Payuhakiri District network leader, and 1 Khao Thong Sub-district fund bachelor were interviewed, they gave recommendations that most of village funds have similar problems but the most important problem is new accounting system because it is complex and needs time to study but it is rather difficult. Other problems are later. However, in order 
to accomplish the village fund success in accordance with philosophy, setting objective, self-dependence, and sustainable development, it must be soved other problems as well.

\subsection{Focus Group Discussion Results}

Focus group discussion, the participants gave various guidelines for problem solving and concluded the results as the followings.

1. Body of knowledge on graduate entrepreneurship, it can be concluded that the guideline of development, holding the entrepreneur camp that emphasized on multi-disciplinary academic together and provide an opportunity for student to have a real practice and continuous promotion for sustainability.

2. Analysis the thinking model on "Development Strategy" from focus group discussion to know problem and components of problem structure and it concluded that information from real existing was analyzed with thinking model on "Development Strategy" by defining and analyzing the target problems as the followings.

2.1) Support fundamental knowledge to be strong and ready to enter to community monetary institute.

2.2) Systemic administration

1. Fund management of committee

2. Member self management and household accounting

3. Use self sufficiency economy

2.3) Accounting Management

1. Accounting principle

2. Skill for income-expense account of village fund

3. Computer applied application for village fund account

2.4) Support for member strength

1. Plan for career based on principle of self sufficiency economy

2. Business implementation based on mixed marketing management with $4 \mathrm{P}$.

3. Household accounting and saving planning for future

4. Planning welfare, and security

5. Network building

Therefore, the village fund manage and members needs to cooperate for strengthen village fund by supporting each other. The manage should understand the new accounting system, introduce the high technology, strength the member with occupation plan and save money based on principle self-sufficiency economy.

\subsection{Experimental Results}

The results of knowledge, attitude, and practical skill changing of the experimental group of the 72 members of village fund showed that their achievement of knowledge, attitude and practical skill had mean different scores of 6.79 between pretest and posttest with statistically significant at level of 0.001 as presented in table 1.

Table 1 Knowledge, Attitude and Practical Skill Different Scores

\begin{tabular}{|c|c|c|c|c|c|c|c|c|}
\hline Treatment & (n) & $\left(\bar{X}_{)}\right.$ & S.D. & $\begin{array}{l}\text { Mean } \\
\text { Difference }\end{array}$ & $\begin{array}{l}\text { S.D. } \\
\text { Difference }\end{array}$ & $\bar{t}$ & df & Sig \\
\hline Pretest & 72 & 22.58 & 3.23 & \multirow{2}{*}{6.79} & \multirow{2}{*}{2.13} & \multirow{2}{*}{$27.066^{\star}$} & \multirow{2}{*}{71} & \multirow{2}{*}{0.000} \\
\hline Posttest & 72 & 29.38 & 2.36 & & & & & \\
\hline
\end{tabular}

Statistically significant level of 0.001

From table 1, the training course of strategic for capacity building in implementing the village fund of knowledge, attitude, and practical skill changing, the experimental group changed their knowledge, attitude, and practical skill had mean different scores of 6.79 between pretest and posttest with statistically significant at level of 0.001 .

\subsection{Satisfaction Result of Capacity Building for Village Fund Implementation}

After training, the satisfaction levels of 72 members who received training course of strategies for capacity building in 
implementing the village fund, the strategy of knowledge, attitude, and practical skill change, it was found that the aspect of knowledge and skill on village fund were covered at highest level of 4.65 and overall average satisfaction of fund members at the high level of 4.00 as presented in table 2 .

Table 2 Satisfaction Result of Capacity Building for Village Fund Implementation

\begin{tabular}{|c|c|c|c|c|}
\hline \multirow[t]{2}{*}{ Item } & \multirow[t]{2}{*}{ Satisfaction Issues } & \multicolumn{2}{|c|}{$\mathrm{n}=72$} & \multirow[t]{2}{*}{ Satisfaction level } \\
\hline & & $\bar{X}$ & S.D. & \\
\hline 1 & $\frac{\text { In put }}{\text { Body knowledge is pertinent to objective. }}$ & 3.67 & \pm 0.63 & High \\
\hline 2 & The aim of training can response to research objective. & 4.04 & \pm 0.57 & High \\
\hline 3 & The aim is in accordance real practice. & 4.10 & \pm 0.51 & High \\
\hline 4 & The content is suitable to activity, and duration. & 4.04 & \pm 0.54 & High \\
\hline 5 & The content is arranged continuously and properly. & 3.85 & \pm 0.66 & High \\
\hline 6 & The content is suitable and useful for participants. & 3.99 & \pm 0.54 & High \\
\hline 7 & $\frac{\text { Process }}{\text { The activities are suitable and possible. }}$ & 3.99 & \pm 0.52 & High \\
\hline 8 & $\begin{array}{l}\text { The set practical activities are congruent to content and } \\
\text { participant. }\end{array}$ & 4.13 & \pm 0.50 & High \\
\hline 9 & $\begin{array}{l}\text { Methods/ activity of training are congruent to content and } \\
\text { objectives. }\end{array}$ & 3.97 & \pm 0.56 & High \\
\hline 10 & Time is suitable for training contents. & 4.13 & \pm 0.47 & High \\
\hline 11 & $\frac{\text { Output }}{\text { Knowledge and skill on village fund are covered. }}$ & 4.65 & \pm 0.65 & Highest \\
\hline 12 & $\begin{array}{l}\text { Knowledge and skill received from training are systemic } \\
\text { administration and application. }\end{array}$ & 3.60 & \pm 0.62 & High \\
\hline 13 & $\begin{array}{l}\text { Knowledge and skill received from training are application of } \\
\text { accounting management for village fund. }\end{array}$ & 4.07 & \pm 0.59 & High \\
\hline 14 & $\begin{array}{l}\text { Knowledge and skill received from training is computer for } \\
\text { accounting and document use. }\end{array}$ & 4.11 & \pm 0.57 & High \\
\hline \multirow[t]{2}{*}{15} & $\begin{array}{l}\text { Knowledge and skill received from training are career choice } \\
\text { and marketing management with } 4 \mathrm{P} \text {. }\end{array}$ & 3.67 & \pm 0.69 & High \\
\hline & Overall & 4.00 & \pm 0.21 & High \\
\hline
\end{tabular}

The satisfaction of 72 members who received training course of strategies for capacity building in implementing the village fund on knowledge, attitude, and practical skill changing, it was found that the aspect of knowledge and skill on village fund were covered at highest level of 4.65 and overall average satisfaction of fund members at the high level of 4.00 .

From table 2, the training course of strategic implementation of knowledge, attitude and practical skill changes, the experimental group had satisfaction at highest level of 4.65 in aspect of Knowledge and skill on village fund are covered. Subsequences were the set practical activities are congruent to content and participant and time is suitable for training contents at high level of 4.13 equally, knowledge and skill received from training are computer for accounting and document use at high level of 4.11, the aim is in accordance real practice at high level of 4.10 , knowledge and skill received from training are application of accounting management for village fund at high level of 4.07 , the aim of training can response to research objective and the content is suitable to activity, and duration at high level of 4.04 equally, the content is suitable and useful for participants ant activities are suitable and possible at high level of 3.99 equally, methods/ activity of training are congruent to content and objectives at high level of 3.97, The content is arranged continuously and properly at high level of 3.85 , body knowledge is pertinent to objective and knowledge and skill received from training are career choice and marketing management with $4 \mathrm{P}$ at high level of 3.67 equally, knowledge and skill on village fund are covered at high level of 3.65 , and knowledge and skill received from training are systemic administration and application at high level of 3.60 respectively. 


\section{Discussion}

Research results illustrated that the most essential of strategies for capacity building in implementing the village fund for fund committees and member are changing knowledge, attitudes, and practical skill to accomplish the efficiency and effectiveness. They need to train to make them know and understand by supporting about fundamental knowledge how to be strong and ready to enter to community monetary institute, systemic administration in terms of fund management of committee, member self management and household accounting, and use self sufficiency economy. Moreover, they need to train for accounting management in terms of accounting principle, skill for income-expense account of village fund, and computer applied application for village fund account. Additionally, they need be support for member strength and be planned for career based on principle of self sufficiency economy, business implementation based on mixed marketing management with $4 \mathrm{P}$, household accounting and saving planning for future, planning welfare, and security and network building to exchange their experiences of village fund implementation. Particularly, the village with unsuccessful implementation should have an opportunity to learn the successful one.

However, they must to use Sufficiency Economy philosophy as basic guideline in living with implementation for fund committee administration with integration of system administration, accounting management, and computer use literacy for keeping up to globalization.

\section{References}

Khao Thong Sub-district. (2011). Three Year Development Plan (B.E. 2554-2556).

National Village and Urban Community Fund Office. (2012). Policy of Village Fund.Retrieved from http://www.villagefund.or.th/index.aspx

Saengthong, K. (2007). Factors Affecting to Effective Administration of Village and Urban Community Fund. Thesis of Master Degree of Political Science . Khon Kaen: Locl Administrative College Khon Kaen University.

The National Economic Development Board Office of the Prime Minister. (1997). The Eighth Economic and Social Development Plan (1997-2001). Retrieved from http://www.nesdb.go.th/Default.aspx?tabid=402

The National Economic Development Board Office of the Prime Minister. (2002). The Ninth Economic and Social Development Plan (2002-2006). Retrieved from http://www.nesdb.go.th/Default.aspx?tabid=402

The National Economic Development Board Office of the Prime Minister. (2007). The Tenth Economic and Social Development Plan (2007-2011). Retrieved from http://www.nesdb.go.th/Default.aspx?tabid=402

The National Economic Development Board Office of the Prime Minister. (2007). The Eleventh Economic and Social Development Plan (2007-2011). Retrieved from http://www.nesdb.go.th/Default.aspx?tabid=402

Thiengkamol, N. (2007). Globalization Administration. Bangkok: Saengchai Publishing.

Thiengkamol, N. (2011a). Holistically Integrative Research. (2nd Edition). Bangkok: Chulalongkorn Press. 